\title{
Influence of changed vegetations fields on regional climate simulations in the Barents Sea Region
}

\author{
Holger Göttel • Jörn Alexander • Elke Keup-Thiel • \\ Diana Rechid • Stefan Hagemann • Tanja Blome • \\ Annett Wolf • Daniela Jacob
}

Received: 5 July 2006 / Accepted: 3 October 2007 / Published online: 27 November 2007

(C) Springer Science + Business Media B.V. 2007

\begin{abstract}
In the context of the EU-Project BALANCE (http://balance-eu.info) the regional climate model REMO was used for extensive calculations of the Barents Sea climate to investigate the vulnerability of this region to climate change. The regional climate model REMO simulated the climate change of the Barents Sea Region between 1961 and 2100 (Control and Climate Change run, CCC-Run). REMO on $\sim 50 \mathrm{~km}$ horizontal resolution was driven by the transient ECHAM4/OPYC3 IPCC SRES B2 scenario. The output of the CCC-Run was applied to drive the dynamic vegetation model LPJ-GUESS. The results of the vegetation model were used to repeat the CCC-Run with dynamic vegetation fields. The feedback effect of the modified vegetation on the climate change signal is investigated and discussed with focus on precipitation, temperature and snow cover. The effect of the offline coupled vegetation feedback run is much lower than the greenhouse gas effect.
\end{abstract}

\section{Introduction}

The global near surface temperature increased since the beginning of the industrialisation. For the twentieth century an increase of about $0.6 \pm 0.2^{\circ} \mathrm{C}$ was quantified (Houghton et al. 2001). The warming was non-uniform over the globe and is expected to be larger in the Arctic than in other regions of the world. For the last 40 years an increase of $1.5^{\circ} \mathrm{C}$ is documented in the Arctic (ACIA 2004), a region which is extremely vulnerable to climate change. With increasing temperature and precipitation and a corresponding decrease of sea ice, permafrost and snow cover, severe impacts on the ecosystems are expected. The societal and economic welfare of the Barents Sea Region is closely connected to the natural environment. The economy is mostly based on fishery, forestry and reindeer herding (Houghton et al. 2001). The impacts on economy and society are investigated by our partners in the BALANCE project (this issue).

H. Göttel $(\bowtie) \cdot$ J. Alexander $\cdot$ E. Keup-Thiel $\cdot$ D. Rechid $\cdot$ S. Hagemann $・$ T. Blome $・$ D. Jacob Max Planck Institute for Meteorology, Bundesstr. 53, 20146 Hamburg, Germany e-mail: holger.goettel@zmaw.de

URL: www.mpimet.mpg.de

A. Wolf

Abisko Scientific Research Station, Royal Swedish Academy of Sciences, 98107 Abisko, Sweden 
Several other studies and international projects investigated the sensitivity of the Arctic to climate change: The Arctic Climate Impact Assessment (ACIA 2004), the Arctic Ocean Model Intercomparison Project (AOMIP, http://fish.cims.nyu.edu/project_aomip/overview. html) and the Arctic Regional Climate Model Intercomparison Project (ARCMIP, http:// curry.eas.gatech.edu/ARCMIP/index.html). The variability of temperature and precipitation in the entire Arctic region has been documented by Przybylak (2002). This includes a summary of available measurement stations from 1880 to 1990 . Regional modelling studies have been performed by Lynch et al. $(1995,2001,2004)$, Dethloff et al. $(1996,2001)$ and Rinke et al. (2006) for example.

Climate change will affect the spatial and temporal distribution of vegetation and these changes can feed back to further changes of the local and regional climate. Until now for the Barents Sea Region the feedback effects have not been investigated in detail. The vegetation distribution affects the regional climate in several ways:

The absorption of solar radiation is controlled by the surface albedo. A change from tundra vegetation with a surface albedo of about $17 \%$ to a cool conifer forest with $13 \%$ changes the surface albedo by $4 \%$. This means that $4.8 \%$ more solar radiation is absorbed and the near surface temperature increases. Apart from the influence of the vegetation albedo also the height of the vegetation plays a dominant role in the snow-covered season. The snow-albedo feedback is a strong positive feedback that is modulated by the annual cycle of solar radiation and by the height of vegetation (Lynch et al. 1998). Tall vegetation (e.g. trees) can protrude the snow pack better than small vegetation (e.g. shrubs). This decreases the snow albedo by snow masking through tall vegetation, an effect that has been seen in surface and satellite observations (Rouse 1984; Robinson and Kukla 1985). A further effect of the vegetation is the change of roughness length. The roughness length describes the impact of vegetation on the near surface wind speed and air turbulences. It directly affects the exchange of moisture, heat energy and momentum between the earth's surface and the atmosphere. Another important parameter is the leaf area index (LAI). The interaction between vegetation and the atmosphere, e.g. precipitation interception, energy conversion due to transpiration and gas exchange, is substantially determined by the LAI. The LAI is an important parameter of the vegetation canopy, and can be used to estimate evapotranspiration, an important component of the hydrological cycle. All effects initiated by changing vegetation characteristics are interacting among each other.

This study highlights the vegetation feedback on climate change in Northern Europe. The main scientific questions addressed in this paper are:

1. What are possible future changes of temperature, precipitation and snow pack under increasing greenhouse gas concentrations in the Barents Sea region?

2. How is the response of the vegetation to climate change?

3. What is the overall feedback effect of changing vegetation type and distribution on precipitation and temperature and what is the impact on precipitation and temperature caused by changes of snow cover, albedo and roughness length?

4. What is the typical frequency of storms influencing the Barents Sea region and how are vegetation changes related to the storm frequency?

In order to address these questions, two different experiments have been performed and compared to each other. In the control and climate change run (CCC-Run) with the regional climate model REMO the vegetation type and spatial distribution of vegetation is constant, with intra-annual changes of background albedo and LAI according to growing and dormancy seasons. In the second run - the climate change and vegetation feedback run (CCVF-Run) - REMO is offline-coupled to a vegetation model. In the CCVF-Run the 
vegetation on the inter-annual scale and the spatial distribution of the vegetation type changes dynamically according to the simulated climate in the CCC-Run. There are several vegetation models available, such as BIOME (Prentice et al. 1992) and SIVM (Cosgrove et al. 2002). These models were used to study the impact of modelled or predicted changes in the climate on the plants distribution and are biogeography models. Other vegetation models also include the carbon cycle to combine biogeography and biogeochemistry. These models, which are often referred to as dynamic vegetation models, are IBIS (Foley et al. 1996) and LPJ (Sitch et al. 2003). The BALANCE project investigates both the effect of changed vegetation on climate change (biogeography) and changes in the carbon cycle (biogeochemistry) by Wolf et al. (2007). Therefore we used a dynamic vegetation model in our study. The LPJ model is widely used with climate models and for different climate conditions. For example, Hickler et al. (2004) used LPJ-GUESS driven by paleoclimate data to study vegetation dynamics at the transition between prairie, hardwoods and boreal forest in the Great Lakes Region of the United States. They showed in the paleoclimatic simulation that LPJ-GUESS successfully predicts the pattern of vegetation. Schurgers et al. (2007) used LPJ and ECHAM4 to simulate the global interaction between vegetation and climate for two interglacials: the Eemian (128-113 kyear B.P.) and the Holocene (9 kyear B.P.). Additionally, long-term simulations of anthropogenic climate change using the IPCC SRES scenarios were carried out. These simulations showed the capability of LPJ to react to extreme climate conditions on a global scale. Here, we coupled REMO with LPJ for the first time. REMO uses the same physical parameterisations as ECHAM4, so that the performance of the combination is like ECHAM4 and LPJ, which was already investigated by Koca et al. (2006) and Schurgers et al. (2007).

Section 2 presents a short description of the models, model domain and the implementation of the dynamic vegetation fields into the model. The focus of Section 3 is to analyse the feedback of vegetation to climate change. The present situation is compared against the period 2081-2100. Seasonal distributions are analysed. Finally, a summary and conclusion of the results are presented in Section 4.

\section{Models and methods}

\subsection{Model description}

To investigate possible future climate development, two climate models and one vegetation model were used. The vegetation model LPJ, the coupled atmosphere ocean general circulation model (AOGCM) ECHAM4/OPYC3 and the regional climate model REMO.

The REgional climate MOdel REMO is based on the "Europamodell," the former numerical weather prediction model of the German Weather Service (Majewski 1991). Further development of the model took place at the Max Planck Institute for Meteorology, where the physical parameterisations from ECHAM4 were implemented into the Europamodell code (Jacob and Podzun 1997; Jacob 2001). Within the international BALTEX (BALtic sea EXPeriment) project (Raschke et al. 1998, 2001; Jacob et al. 2005) the model has been validated, further developed and applied to study the hydrological cycle in the Baltic Sea catchments (Lehmann et al. 2004). In recent years the application of REMO has been extended to other regions of the world - including Polar Regions and to climate projections into the future (Pfeifer and Jacob 2005; Jacob et al. 2005). All REMO experiments presented here were carried out on a $0.5^{\circ}$ horizontal resolution and 20 unequally spaced vertical levels. The lateral atmosphere driving fields are taken from an 
AOGCM ECHAM4/OPYC-T42 IPCC B2 experiment. The model domain including the relaxation zone is shown in Fig. 1. For further validation the present day climate of the Barents Sea region has been simulated using REMO (baseline run) driven by ECMWF Reanalysis (1979-1993) and ECMWF operational analysis data (1994-2000) with the same model domain as used for the CCC run. Keup-Thiel et al. (2006) showed in the validation a good agreement with observations.

In this application the AOGCM ECHAM4/OPYC3 (Roeckner et al. 1996; Oberhuber 1993) a spectral model with an equivalent horizontal resolution of $2.8^{\circ}$ and 20 unequally spaced vertical levels. The ocean component is a grid point model of $3^{\circ}$ and 40 unequally spaced vertical levels.

The LPJ dynamic vegetation model (Smith et al. 2001) is a consortium model developed at Lund University, Potsdam Institute of Climate Impact Research and Max Planck Institute for Biogeochemistry in Jena. The LPJ-GUESS incorporates a coupled photosynthesis water balance scheme, plant resource competition, population dynamics, fire disturbance and soil biogeochemistry. In this simulation The LPJ simulations are carried out on $0.5^{\circ}$ spatial resolution, the same as used in REMO, and is driven by monthly near surface air temperature, snow depth, precipitation and cloud cover computed with REMO in the CCC-Run.

The AOGCM simulation started in 1860 with sea surface temperatures (SST) close to those of 1990 and has therefore a warm bias in the SST. It was suggested by Roeckner et al. (1999) to analyse only differences to the reference period. The objective of the BALANCE project is to assess the vulnerability of the Barents Sea region with a wide range of methods, e.g. a suite of models for different sectors. The models require absolute values and need the present day climate conditions as accurately as possible in order to examine the impact of climate change. For instance, a temperature bias results in a significant impact on vegetation carbon uptake (Wolf et al. 2007). Therefore the meteorological data of near surface temperature and precipitation for the future climate were corrected with a method similar to the "delta change approach" (e.g. Andréasson et al. 2004) so that they could be used directly by the LPJ-GUESS model.
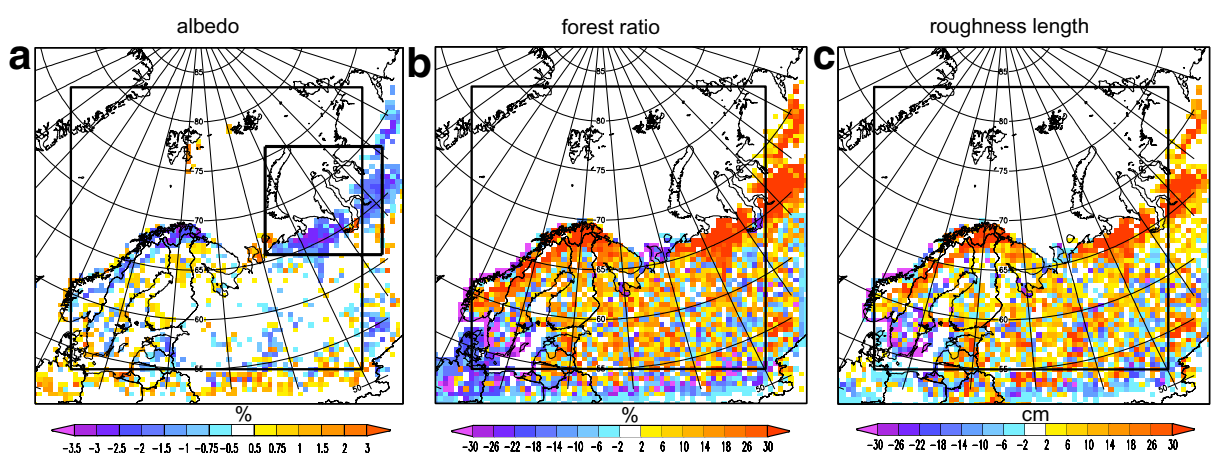

Fig. 1 Differences, CCVF minus CCC-Run, from left to right of a albedo [\%], b forest ratio [\%] and c roughness length $[\mathrm{cm}]$ for the time slice 2080-2099. The relaxation zone is marked by the larger rectangular. Siberian sub domain is marked by the smaller rectangular 
For temperature the climatological annual cycle for the time-slice 1979-2000 of the $\mathrm{CCC}$ run and the baseline run were calculated. The monthly mean differences between the climatological cycles were used to correct the daily and monthly values of the CCC run. The same monthly correction factors were used for all days. Precipitation and evaporation were be handled similarly, but with relative changes. There was no correction, if the climatological monthly sum of evaporation or precipitation is less than $3 \mathrm{~mm} / \mathrm{month}$. This was done to avoid spurious high values in the future. The advantage of this method is that the changes in extremes and the variability are conserved compared to the method of Andréasson et al. (2004), but the disadvantage of this procedure is the same change factors for different temperature values. The correction of temperature and precipitation also influence the snow pack. Therefore the Simplified Land surface (SL) scheme (Hagemann and Dümenil 2003) is used to calculate the snow depth based on the corrected precipitation and temperature fields. The snow pack is represented as a single layer and changes its depth by snowfall and snowmelt. The snowfall is calculated by separation of precipitation into rain and snow with a temperature relationship according to Wigmosta et al. (1994). For snowmelt the SL scheme used a daily degree formula according to the HBV model (Bergström 1992) and a sinusoidal correction is applied to the degree-melting factor. The delta change approach and the snow correction are simplified methods. However, this was the most appropriate method at present. The delta change approach was discussed with all BALANCE partners and used throughout the BALANCE project.

\subsection{Method}

To estimate the vegetation feedback on climate change three different experiments have been carried out. In the first experiment (CCC-run) REMO has been driven by the transient ECHAM4/OPYC3-T42 IPCC SRES B2 scenario. This experiment has been performed to simulate the climate change of the Barents region from 1961 to 2099 due to enhanced greenhouse gas emissions. Secondly, a dynamical vegetation experiment on $0.5^{\circ}$ spatial resolution, the same resolution as used in REMO, was calculated with LPJ-GUESS to estimate the response of vegetation types and spatial distribution of vegetation to climate change. Thirdly, a vegetation feedback experiment (CCVF-run) in which the climate change scenario was rerun using REMO again, but with a modified spatial distribution of vegetation types from the LPJ-GUESS experiment. The differences of both climate scenarios can then solely be dedicated to the changes in vegetation.

The vegetation land surface processes in REMO are controlled by physiological vegetation properties like leaf area index (LAI), fractional vegetation cover $(V)$, background surface albedo $(A)$, surface roughness length due to vegetation $\left(Z_{\mathrm{veg}}\right)$, forest ratio $(F)$ and water holding capacity $\left(\mathrm{WS}_{\max }\right)$. The parameter values for the CCC-Run are taken from a global dataset of land surface parameters (LSP). Hagemann et al. (1999) and Hagemann (2002) derived the LSP from a global distribution of major ecosystems (96 types after Olson 1994) which is available from the US Geological Survey. It defines the physiological vegetation properties for each ecosystem and aggregated the LSP datasets for the use in REMO.

The result of the LPJ-GUESS dynamic vegetation run consists of three sets of data.

1. Forest ratio

2. Non-forest ratio (all areas occupied by vegetation not being forest)

3. Leaf area index 
The data were provided for the period from 1961 to 2099 with forest ratio and non-forest ratio as annual means and leaf area index as monthly means.

A problem to concerning the implementation of the output of the vegetation run was found in the initial forest distribution of Hagemann (2002) and LPJ-GUESS. The forest distribution of Hagemann (2002) can be considered as quasi-observed dataset (satellite data product). The forest distribution of LPJ-GUESS is a state of equilibrium derived after a 1,000-year spin-up period, driven by the meteorological quantities from the CRU timeseries from 1901 to 1930 repeatedly to provide the climate input for the spin-up (Wolf et al. 2007). LPJ-GUESS provides a "present-potential" vegetation, without human influence, e. g. deforestation and additional simulation biases. The differences between these two datasets for forest ratio range between $\pm 20 \%$. We assume that the bias in the simulation is the same for the future scenario. Therefore, the bias in the LPJ-GUESS is corrected by subtracting of a constant bias. The vegetation ratio of each vegetation type is limited between 0 and $100 \%$.

Two assumptions were made to achieve the temporal and spatial varying land surface parameters (LSP):

1. An increase in the percentage of forest in each grid box is solely based on a decrease of bare soil and other vegetation types like shrubs.

2. The LSP for forest in the Barents region are the same for the entire model domain. This means only one type of forest exists in the model domain.

To get the LSP for the LPJ-GUESS forest type the LSP values of typical forest types in the Barents region were averaged. A new LSP dataset for the LPJ-GUESS forest type was established.

For areas occupied by glacier, inland water, ocean, urban areas and wetlands the LSP could be allocated using Hagemann (2002). All other possible vegetation types and bare soil were aggregated to a new ecosystem type called non-forest/bare-soil. The LSP values for non-forest/bare-soil were calculated for each grid box separately by subtracting all other values:

$$
\mathrm{LSP}_{\text {non-forest }}=\mathrm{LSP}_{\mathrm{REMO}}-\sum_{i=1}^{6} A_{i} \times \mathrm{LSP}_{i}
$$

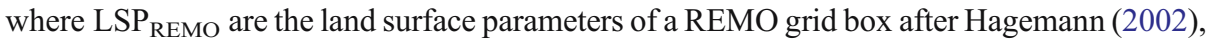
$\mathrm{LSP}_{\mathrm{i}}$ are the parameters of forest, glacier, inland water, ocean, urban areas and wetlands and $\mathrm{A}_{\mathrm{i}}$ the fraction of forest, glacier, inland water, ocean, urban areas and wetlands.

This method was applied to all grid boxes separately, resulting in LSP values for all defined ecosystem types, e.g. glacier, inland water, ocean, urban areas, wetlands and nonforest/bare-soil, in the CCVF-Run. The LSP values of non-forest/bare-soil vary over the model domain depending on Eq. 1.

The aggregated LSP values of the dynamic ecosystem types control the vegetation land surface processes in REMO. These are: leaf area index (LAI), fractional vegetation cover $(V)$, background surface albedo $(A)$, surface roughness length due to vegetation $\left(Z_{\mathrm{veg}}\right)$, forest ratio $(F)$ and water holding capacity $\left(\mathrm{WS}_{\max }\right)$ and represent the development of forest growth, of functional plant cover and of the density of vegetation. The differences, CCVFRun minus CCC-run, of annual means over 20 years of $A, F$ and $Z_{\mathrm{veg}}$ for the time slice 2080-2099 are shown in Fig. 1. $F$ affects the LAI. LAI, $Z_{\text {veg }}$ and $A$ turned out to be the dominant parameters for climate model simulations (Rechid and Jacob 2006). 
A Mann-Whitney- $U$ Test ( $U$ Test) was applied to test the significance of the differences between the CCC run and the CCCV run. This is a ranking test, it does not assume a normal distribution like other standard methods (e.g. student- $t$ test).

\section{Results}

\subsection{Climate change signal}

The analysis of the CCC-run describes the possible changes in the Barents Sea region based on the IPCC SRES B2 scenario (Houghton et al. 2001). The IPCC/SRES B2 storyline emphasises a world in which sustainability is accomplished through local solutions for economic, social and environmental issues. The greenhouse gas concentration, like $\mathrm{CO}_{2}$, is moderately increasing, as well as the global population. The economic development has an intermediate level. The changes of the aerosols such as $\mathrm{SO}_{4}$ were not considered in our simulation. Only a standard background concentration for $\mathrm{SO}_{4}$ was used.

Four time slices of a 20-year length (1981-2000, 2011-2030, 2041-2060 and 20802099) have been investigated to analyse changes in temperature, precipitation and snow, which are important factors for plant productivity in the Barents Sea Region. For example, the duration of the non-snow season and the timing of the spring melt has a great impact on the surface energy balance and on plant productivity in the Arctic. For a similarly region the boreal forest in Canada - Kimball et al. (2000) found a relationship between the date of first thaw and biomass production. They have shown a decrease of net primary production by $9-17 \%$ for 10 -day delay in spring thaw. Precipitation (liquid) has no effect on plant growth in the Barents region since there is always enough plant available soil water.

The annual mean near surface temperature (defined $2 \mathrm{~m}$ above ground) shows a clear trend, the temperature increases by up to $7^{\circ} \mathrm{C}$ at the end of the twenty-first century. This is three times higher than the global mean temperature trend reported in the third IPCC assessment report (Houghton et al. 2001) for the B2 scenario. The reasons for the high temperature effect in the Barents Sea and also the validation of REMO for this region are discussed by Keup-Thiel et al. (2006). The changes are stronger in winter than in summer (see Fig. 2), which implies that the decrease of snow cover length is stronger than expected. The number of snow days (October to March), here defined as days with more than $3 \mathrm{~cm}$ snow cover, is decreasing heavily until the end of the twenty-first century. The isoline of 120 snow days per year moves about $200 \mathrm{~km}$ northwards and to higher elevations (Fig. 3) when comparing 2080-2099 to 1981-2000. In general there is more precipitation in the future but with large differences between the seasons (see Fig. 4). In winter the precipitation shows a clear positive trend. The largest increase occurs over West-Siberia and the Kara Sea at the end of the twenty-first century. For the summer the precipitation rate anomaly fields have different structures compared to those occurring during winter. An increase of the precipitation over Greenland, Scandinavia and the Baltic Sea is evident for all periods. For other regions, like Siberia, the precipitation rate decreases for the first period (2011-2030) and increase for the last period (2080-2099). This variability is initiated by decadal to multi-decadal variabilities of atmospheric circulation modes like the North Atlantic Oscillation (Hurrel et al. 2003) and Arctic Oscillation (Dethloff et al. 2006).

The changes in temperature and snow cover lead to a shift of tree lines to higher altitudes and latitudes. The largest differences are found for the latest time slice, in which the warming signal is strongest. Therefore, the analysis of the vegetation feedback concentrates on the time slice 2080-2099. 

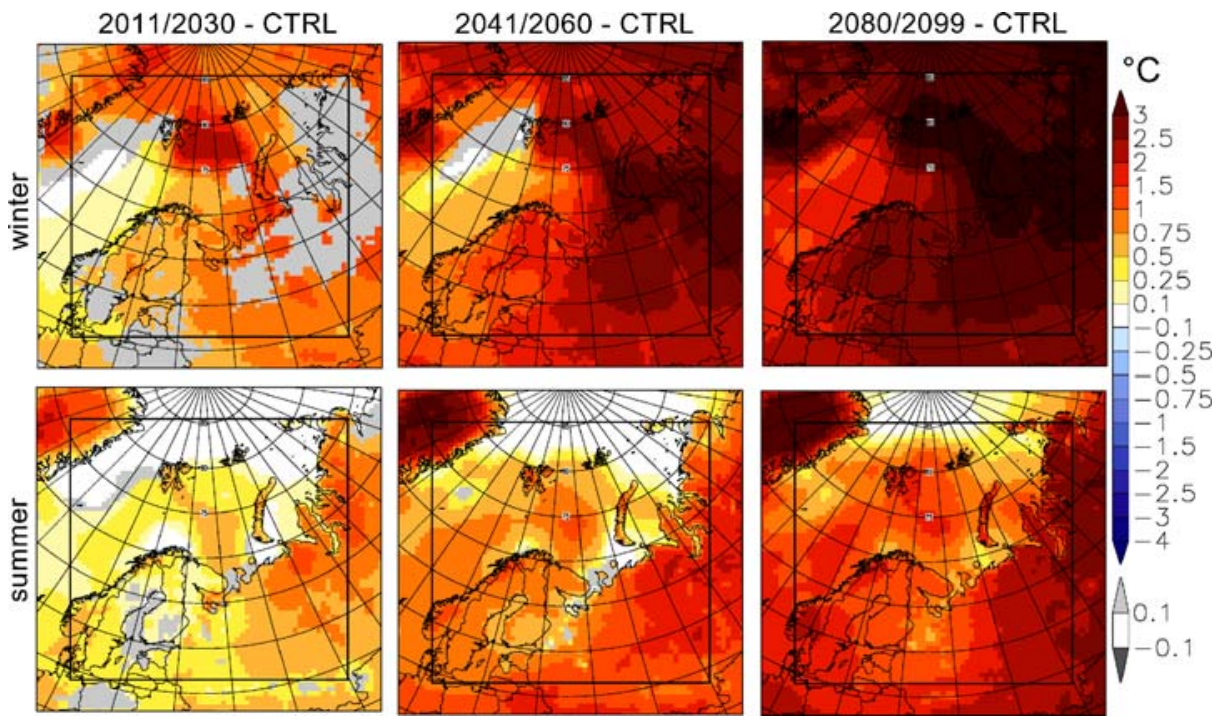

Fig. 2 Seasonal-mean near-surface air temperature differences in ${ }^{\circ} \mathrm{C}$, future time slice minus control period (1981-2000), for three time slices from left to right: 2011-2030, 2041-2060 and 2080-2099 and for winter (top) and summer (bottom). Shown in colour are only values with greater than $95 \%$ confidences

Snow Days in Winter (October to March)

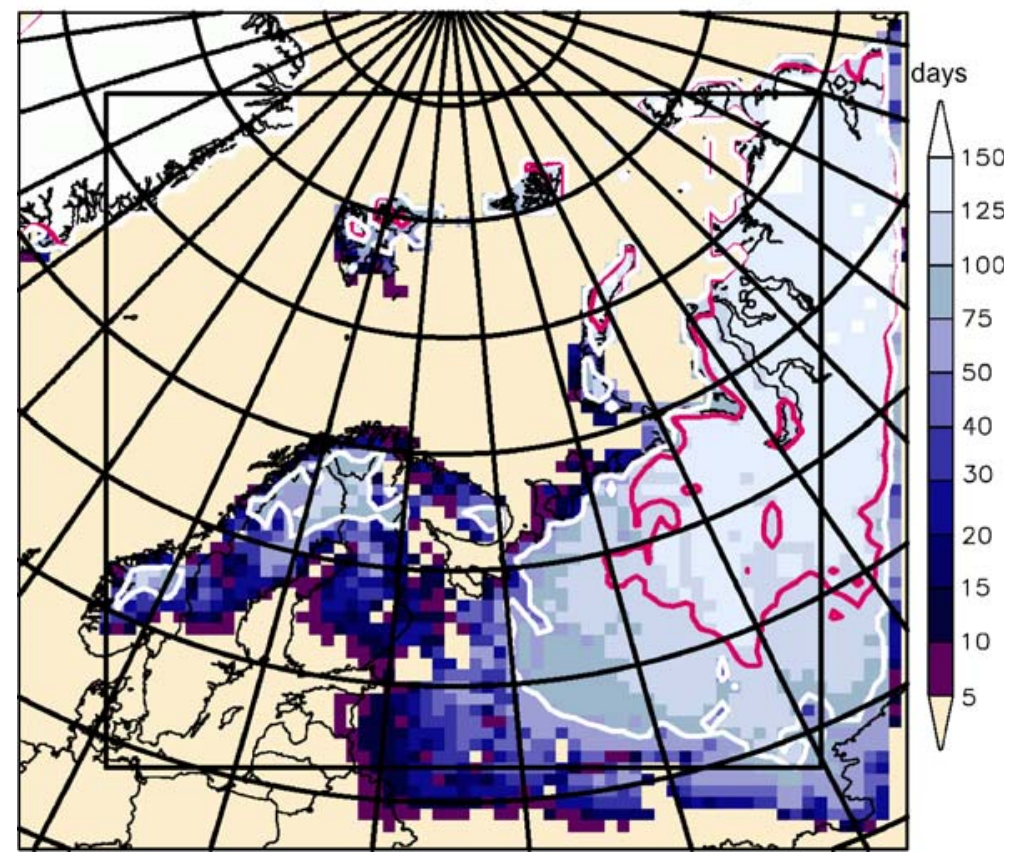

Fig. 3 Number of "snow days" over land, with a snow depth of more than $3 \mathrm{~cm}$ water equivalent, for winter (October to March) mean over 20 years (2080-2099). The areas with more than 120 snow days per year are marked by the white (1981-2000) and purple (2080-2099) lines 

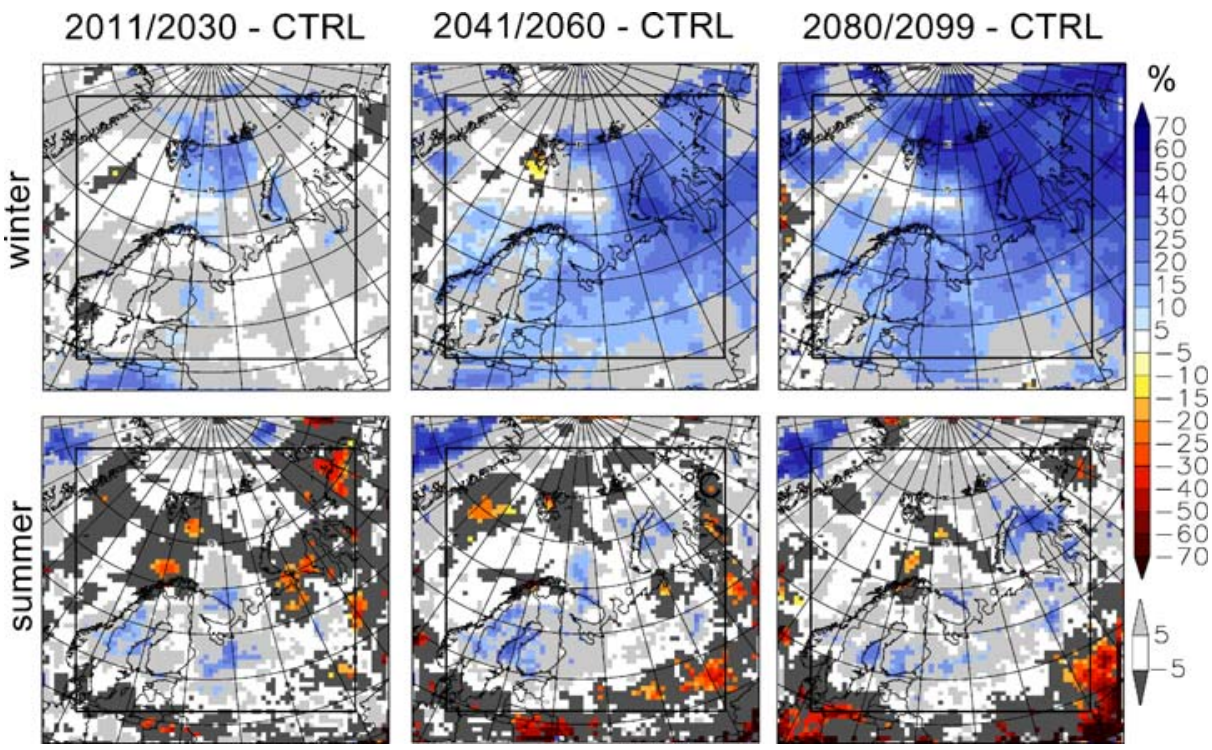

Fig. 4 Differences, future time slice minus control period (1981-2000), in relative percentage change in precipitation for three time slices from left to right: a 2011-2030, b 2041-2060 and c 2080-2099 and for winter (top) and summer (bottom). Shown in colour are only values with greater than $95 \%$ confidences

\subsection{Vegetation feedback}

Seasonal horizontal differences between the CCC and CCVF-runs for the time-slice 2080 to 2099 are presented to identify vegetation feedbacks. The changed land surface parameter values, which control vegetation land surface processes in REMO are shown in Fig. 1. The near surface temperature differences are shown in Fig. 7. The differences for winter (DJF) and autumn (SON) are less than $\pm 0.5^{\circ} \mathrm{C}$ and therefore negligible. Only in spring and summer differences are significant. In spring the highest changes occur over Siberia with a warming of up to $1^{\circ} \mathrm{C}$. This area shows a strong increase in forest cover (see Fig. 1), due to the vegetation change from tundra to boreal forest. Contrary to spring, in summer a cooling of up to $-1.5^{\circ} \mathrm{C}$ could be analysed for Siberia.

The reason for these two opposed trends can be explained by two different mechanisms of vegetation feedback. In spring, it is the well-documented snow-albedo-effect (see Fig. 5). The cooling trend in summer is related to stronger evaporation due to higher transpiration.

It is clear that the absorbed short-wave radiation is the largest energy input of the land surface. The absorption is controlled by the surface albedo, and therefore the surface energy budget is very sensitive to changes in this quantity. The albedo of non-forest/bare-soil is influenced through snow cover. If the vegetation changes from non-forest/bare-soil to forest, the albedo decreases and the new, taller vegetation is not or only partly covered by snow (Strack et al. 2004). Here, wind has an influence and should be accounted for (Hedstrom and Pomeroy 1998). Since the snow is only partly masking the vegetation, the large difference in albedo between forest and snow leads to a warming of the land surface and near surface atmosphere. The albedo of forest in winter ranges from 15 to 30\% (Betts and Ball 1997). For snow the albedo is $\sim 70 \%$. Between the CCC-run and CCVF-run the forest cover in Siberia changes around $30 \%$ (see Fig. 1) and the albedo changes by about $5 \%$ in winter and $0.5 \%$ in summer (Fig. 6). In comparison to other studies and observations (e.g. Schurgers et al. 2007, 

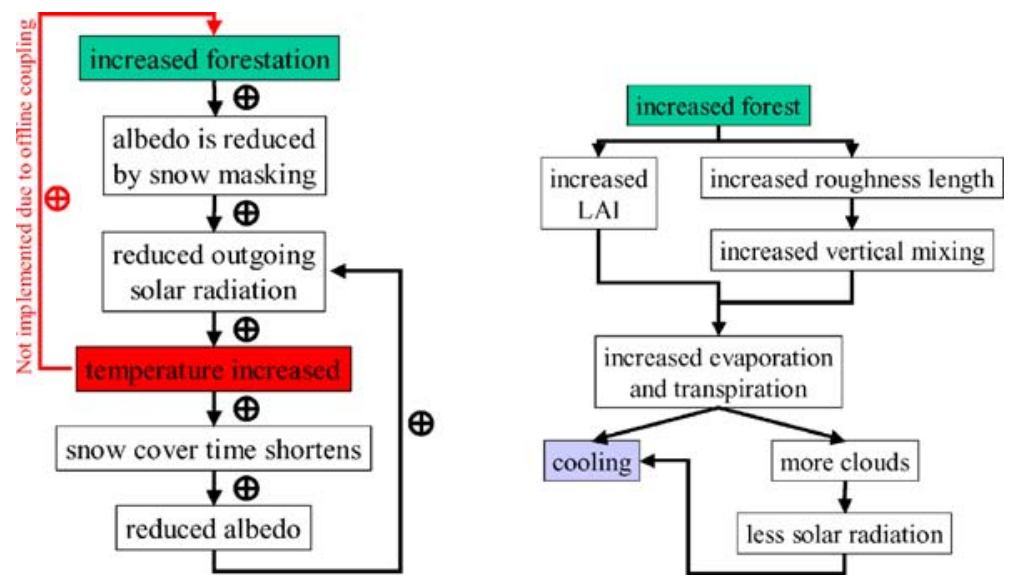

Fig. 5 Major pathways (simplified) on which forest ratio changes near-surface temperature: Spring snow masking feedback loop (left) and chain of causation for cooling in summer (right)

Betts and Ball 1997) the impact of changing surface albedo is too low in our study. Schurgers et al. (2007) have shown for paleoclimate simulations a change of albedo of up to $20 \%$ for the northern hemisphere $\left(60-90^{\circ}\right)$ under a change of the forest cover of $50 \%$.

The small differences in this study are a result of the low albedo differences between non-forest/bare-soil (17\%) and forest (14\%). Beringer et al. (2005) for example have found surface albedo differences of about $9 \%$ between tundra (shrubs and bare soil) and taiga (forest) in observations.

However for the short timeframe of a century the low changes may be realistic. Pioneer trees like birches having a higher albedo are only slowly followed by dark conifers.

The higher energy budget in spring leads an accelerated snow melting and a warming of the near surface temperature (Fig. 7). An extending growing season length is the consequence. Higher plant productivity leads to further movement of the tree line, extending northward and to higher latitudes. This is a positive feedback, which is not

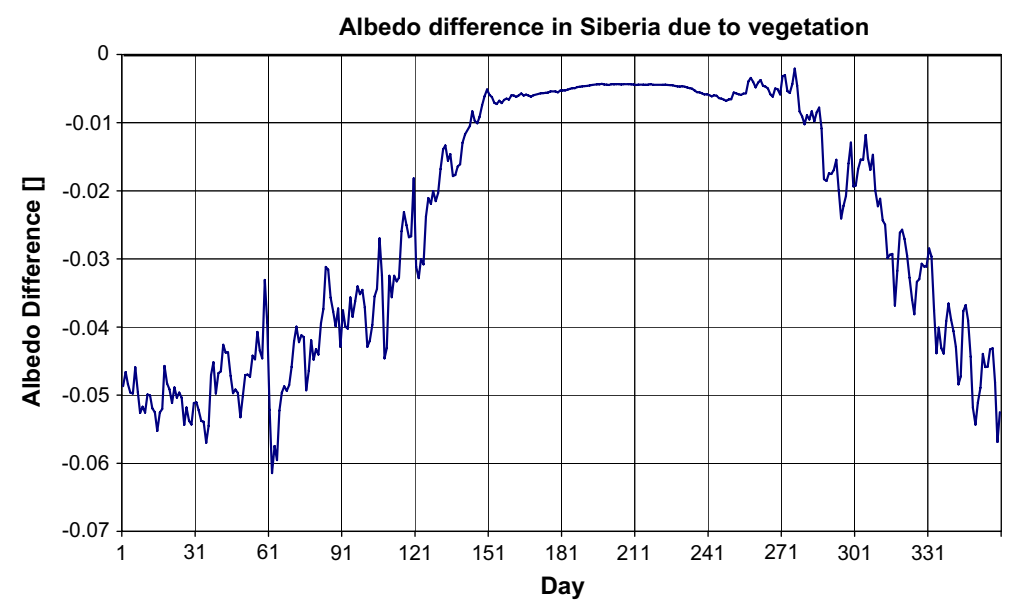

Fig. 6 Differences, CCVF minus CCC-run for 2080-2099, of seasonal cycle of land surface albedo for Siberia; the area of Siberia is marked in Fig. 1. Shown are 5 day running means 

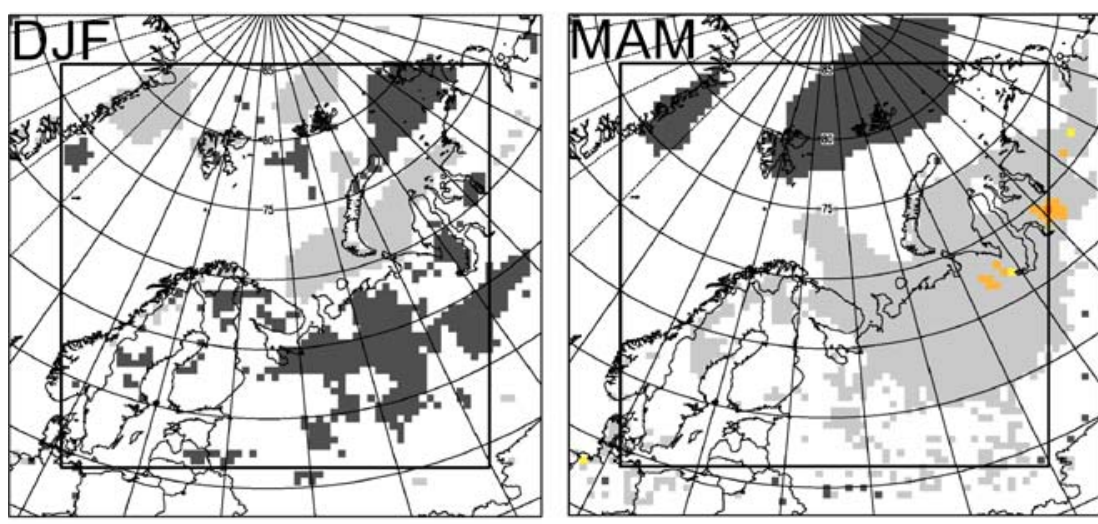

${ }^{\circ} \mathrm{C}$
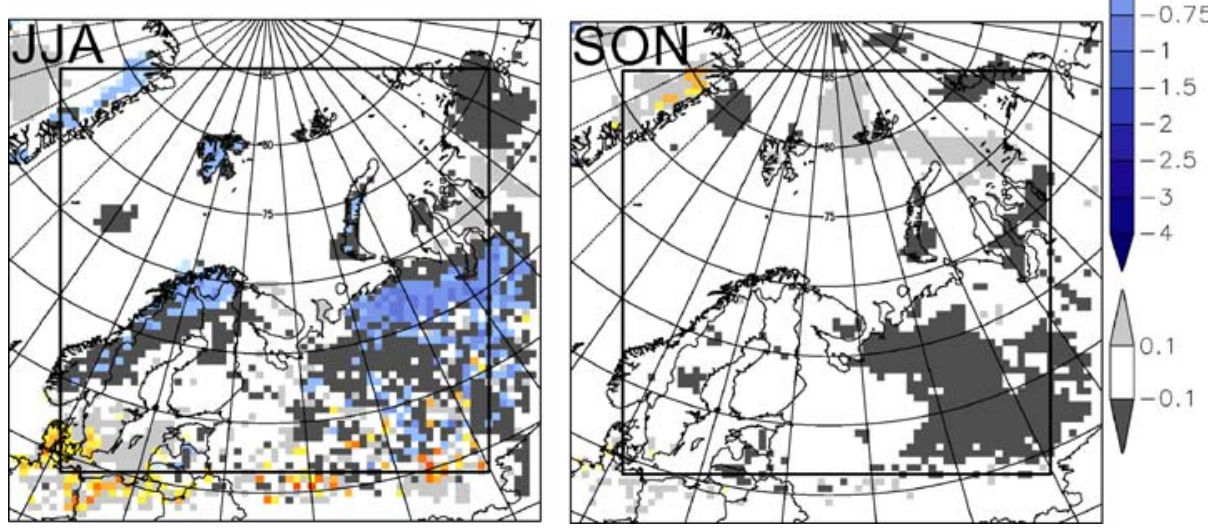

Fig. 7 Seasonal-mean near-surface air temperature difference in ${ }^{\circ} \mathrm{C}$, CCVF minus CCC-Run, averaged over 20 years (2080-2099) for winter $(D J F)$, spring (MAM), summer $(J J A)$, autumn $(S O N)$. Shown in colour are only values with greater than $80 \%$ confidences

captured by an offline feedback procedure. This effect is one magnitude smaller than the greenhouse gas forcing. Therefore, the effect is negligible for the near surface temperature climate prediction. For other studies like $\mathrm{CO}_{2}$ uptake by plants or for forestry and reindeer impact studies the feedback effect must be considered.

The summer cooling is concentrated over Russia/Siberia, where high forest ratios and strong differences in the roughness length between the two climate simulations exist. Through the higher roughness length in the CCVF-run vertical mixing is enhanced and together with higher transpiration rates resulting from increased forest ratio the evaporation is strengthened. The energy transfer by transforming water into water vapour cools the near surface temperature and moistens the air, which produces more clouds. The clouds reduce the incoming solar radiation and boost the cooling of the near surface temperature. The splitting of the two effects is not investigated in this study. This study does not include the stomatal reduction through the increased $\mathrm{CO}_{2}$ concentration. Stomata control the transpiration and under higher $\mathrm{CO}_{2}$ concentration Wagner (1998) expects a reduced stomata density. This will lead to a reduction of the enhanced summer evaporation.

The enhanced summer evaporation and increased cloud cover have no impact on precipitation in this area. The differences of precipitation are shown in Fig. 8. The precipitation changes due to vegetation changes are negligible for winter (DJF), spring (MAM) and autumn (SON). The largest differences in summer are located over sea and 

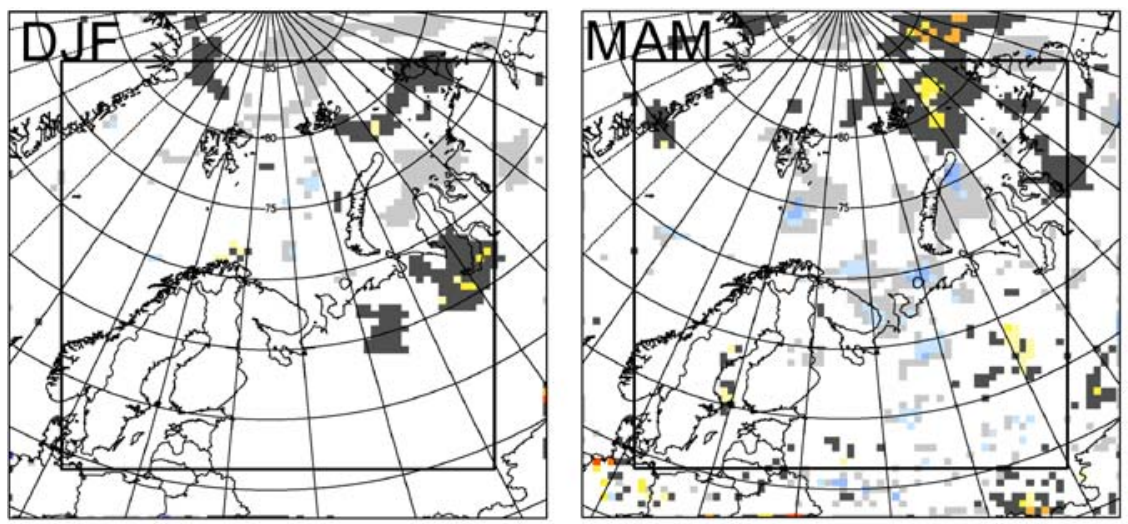

$\%$
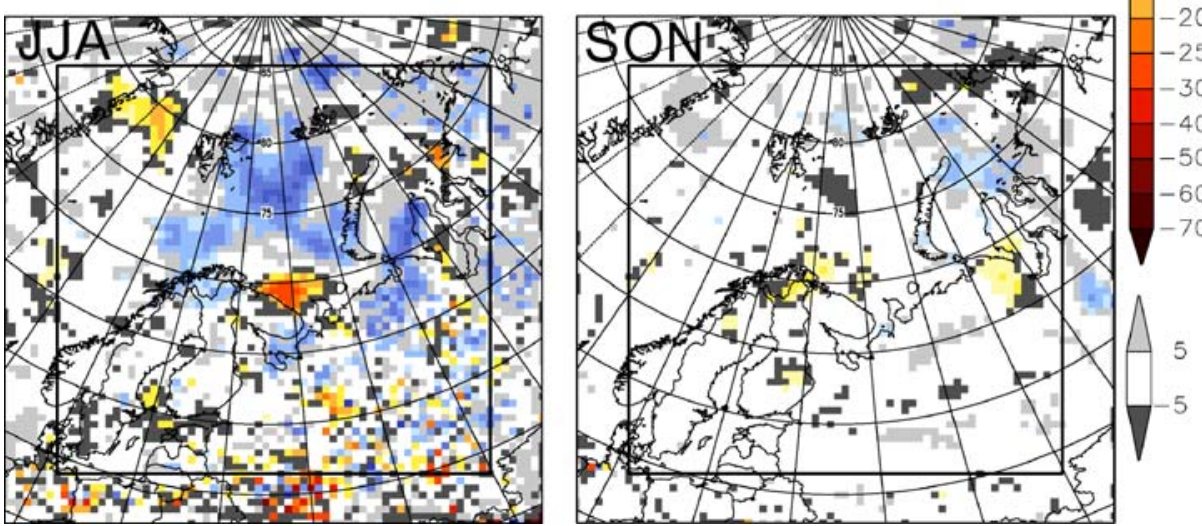

Fig. 8 Differences, CCVF minus CCC-Run for 2080-2099, in relative percentage change in precipitation [\%] for winter $(D J F)$, spring $(M A M)$, summer $(J J A)$ and autumn $(S O N)$. Shown in colour are only values with greater than $80 \%$ confidences

over the Siberian coast with anomalies of more than $20 \%$. Over the area of high evaporation in the region of the central Ural Mountains the precipitation anomaly is very noisy. The moistened air is transported northwards and produces more precipitation in the North and lost to the high evaporation area.

Besides the feedback on the standard climate parameters precipitation and temperature possible changes in storm frequency were investigated. Storm events have a large impact for forestry; breaking twigs of trees and uprooting trees. Normally storms are defined as winds that exceed 10 Beaufort or $25-28 \mathrm{~m} / \mathrm{s}$. Storms only rarely occur inland and are characterized by strong winds with small scale gusts. In this study a storm (or better strong winds) is defined as the $95 \%$ percentile of the daily maximum wind speed for the control period (1961-2000). The reason for this definition is the statistical robustness and the grid cell size of $\sim 55 \times 55 \mathrm{~km}$. Brasseur (2001) has reported that wind gusts associated with storms over Europe are characterized by a turbulent transport of momentum from the top of the boundary layer to the surface. The turbulent transport results in small-scale events less than the grid cell size. In REMO wind is represented for an entire grid box. In this study an event is defined as a wind stronger than the $95 \%$ percentile that occurs with a minimum interval from the preceding simulated event of at least $72 \mathrm{~h}$ and acts as an indicator for strong winds. 
The changes in the number of wind events that exceed the $95 \%$ percentile wind speed (defined for 1961-2000) for the CCC-run are shown in Fig. 9a. The frequency increases by about five events per year for the last four decades (2060-2099) compared to 1961-2000. This is an increase of up to $30 \%$. The lowest changes are located over the Ural Mountains and the largest changes over Siberia and northwest Russia. The increase is caused by changes in the probability density function. The probability density function of daily wind speeds changes as follows: the mean value increases and the standard deviation slightly decrease between the two 40 year time slices (1961-2000 and 2060-2099). The cyclone frequency in the model domain is not changed. From global analysis Bengtsson et al. (2006) found that the cyclone activity is not changed but moved towards higher latitudes.

The changes of vegetation slightly influence the strong wind events. In the $95 \%$ percentile wind frequency anomaly field for yearly means (see Fig. 9b) the frequency increase in the eastern part of the model domain and decrease in the west between the two climate runs for the last time slice. The changed vegetation results in an increase of high wind speed over areas with forest growth and also in the downwind direction. The increase can be explained by the change in the roughness length. The increased roughness length has two major effects on the storm. First, it increases the kinetic energy transfer from the atmosphere to the surface. This has a tendency to weaken the storm. However, increased roughness length has also a positive effect on the latent heat flux. A stronger latent heat flux has the tendency to increase the intensity of storms. The release of the latent heat takes place not only over the areas of enhanced evaporation but also in the downstream region. This leads to intensification in the North, where also precipitation is intensified.

\section{Summary and conclusions}

Two regional climate simulations, one with temporal variable vegetation and one with temporal static vegetation, have been compared. Both were run with REMO using a $0.5^{\circ}$ horizontal resolution (about $55 \times 55 \mathrm{~km}$ ), driven by ECHAM4/OPYC3-T42 IPCC B2 for the period 1961-2099. The increased greenhouse gas concentration in the IPCC B2 scenario leads to a strong future warming in the Barents Sea region (2080-2099) of about $7^{\circ} \mathrm{C}$ in winter, which is three times higher than the global mean temperature trend as reported in

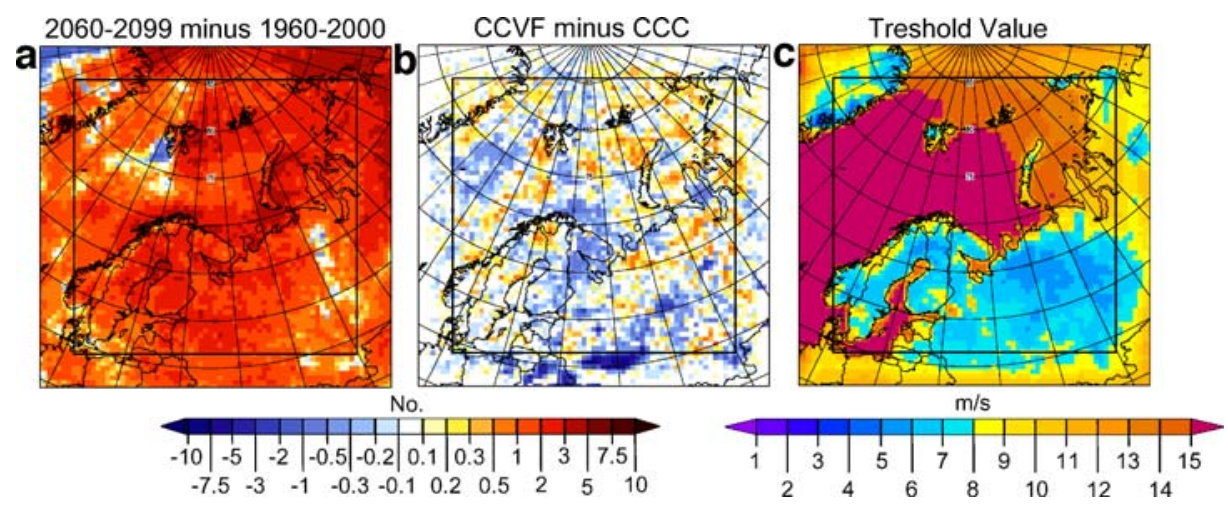

Fig. 9 a Changed number of wind events that exceed the 95\% percentile (defined for the period 1961-2000) due to climate change for a 40 year period (2060-2099 vs. 1961-2000) and b due to vegetation changes (right) for a 40 year period (2060-2099) and $\mathbf{c}$ the $95 \%$ percentile threshold value in $\mathrm{m} / \mathrm{s}$ are shown 
the third IPCC assessment report for the B2 storyline. The annual mean precipitation shows a clear positive trend and increases by about $18 \%$ for the period $2080-2099$ relative to the earlier period 1981-2000. The increase is stronger in winter than in spring and autumn. In summer the precipitation shows a high temporal variability.

The forest ratio increases in the future and the tree line moves to higher altitudes and latitudes. The forest growth in the dynamic vegetation model LPJ-GUESS is caused by a warmer climate with longer snow-free periods and growing season lengths in the Barents Sea Region. This study investigates the vegetation feedback on climate change. The feedback effects are one order of magnitude lower than the effects of greenhouse gas forcing. The seasonal mean temperature difference for the last time slice amounts to about $+1.0^{\circ} \mathrm{C}$ for spring and $-1.5^{\circ} \mathrm{C}$ for summer in Siberia. The warming in spring is a result of the snowalbedo-effect. The cooling in summer can be dedicated to changes of roughness length, enhanced transpiration and changes in surface albedo. The precipitation is slightly affected by the vegetation feedback. Schurgers et al. (2007) has shown larger differences in temperature and albedo changes. The albedo differences between non-forest/bare-soil to forest are 5\% in our study for winter in comparison to observed differences from 15 to $30 \%$ (Betts and Ball 1997). However for the short timeframe of a century the new forest is dominated by bright pioneer trees like birches and not by dark conifers.

The effect of the first iteration of the offline-coupled vegetation feedback run is much lower than the greenhouse gas effect. This suggests that the first iteration is a good approximation for a fully coupled regional atmosphere vegetation model under the condition of short time periods and low albedo changes. In further investigations the results will be compared with a fully coupled model and for larger albedo changes.

The frequency of strong wind events influencing the Barents Sea region is enhanced under warmer climate. The vegetation slightly intensifies the frequency by an enhanced latent heat flux.

All these results are obtained by one realisation. The results of regional climate models can vary depending on the driving fields and are sensitive in terms of large-scale teleconnection patterns like the Arctic Oscillation and the North Atlantic Oscillation. In further studies an ensemble approach could give the confidence interval for the climate change and feedback signal.

Acknowledgements We thank Ralf Podzun for technical support with REMO. Additionally we thank Guy Schurgers for the internal review of this paper. This work has been supported by the Fifth Framework Program of the European Commission (1998-2002) within the Program on Energy, Environment and Sustainable Development (BALANCE, EVK2-CT-2002-00169).

\section{References}

ACIA (2004) Impacts of a warming Arctic climate impact assessment. Overview report. Cambridge University Press, Cambridge, p 146

Andréasson J, Bergström S, Carlsson B, Graham LP, Lindström G (2004) Hydrological change - climate change impact simulations for Sweden. Ambio 33:228-234

Bengtsson L, Hodges K, Roeckner E (2006) Storm tracks and climate change. J Climate 19:3518-3543

Bergström S (1992) The HBV Model - its structure and applications, SMHI Reports Hydrology no. 4, Norrköping Beringer J, Chapin FS, Thompson CC, McGuire AD (2005) Surface energy exchanges along a tundra-forest transition and feedbacks to climate. Agric For Meteorol 131:143-161

Betts AK, Ball JH (1997) Albedo over the boreal forest. J Geophys Res 100:28901-28913

Brasseur O (2001) Development and application of a physical approach to estimating wind gusts. Mon W Rev 129:5-25 
Cosgrove B, Barron E, Pollard D (2002) A simple interactive vegetation model coupled to the GENESIS GCM. Glob Planet Change 32:253-278

Dethloff K, Rinke A, Lehmann R, Christensen JH, Botzet M, Machenhauer B (1996) A regional climate model of the Arctic atmosphere. J Geophys Res 101:23401-23422

Dethloff K, Abegg C, Rinke A, Hebestadt I, Romanov V (2001) Sensitivity of Arctic climate simulations to different boundary layer parameterizations in a regional climate model. Tellus 53A:1-26

Dethloff K, Rinke A, Benkel A, Koltzow M, Sokolova E, Saha SK, Handorf D, Dorn W, Rockel B, von Storch H, Haugen JE, Roed LP, Roeckner E, Christensen JH, Stendel M (2006) A dynamical link between the Arctic and the global climate system. Geophys Res Lett 33:L03703

Foley J, Prentice I, Ramankutty N, Levis S, Pollard D, Sitch S, Haxeltine A (1996) An integrated biosphere model of land surface processes, terrestrial carbon balance, and vegetation dynamics. Glob Biogeochem Cycles 10:603-628

Hagemann S, Botzet M, Dümenil L, Machenhauer B (1999) Derivation of global GCM boundary conditions from $1 \mathrm{~km}$ land use satellite data, MPI Report no. 289. Max Planck Institute for Meteorology, Hamburg

Hagemann S (2002) An improved land surface parameter dataset for global and regional climate models, MPI Report no. 336. Max Planck Institute for Meteorology, Hamburg

Hagemann S, Dümenil L (2003) Improving a subgrid runoff parameterization scheme for climate models by the use of high resolution data derived from satellite observations. Clim Dyn 21:349-359

Hedstrom NR, Pomeroy JW (1998) Measurements and modelling of snow interception in the boreal forest. Hydrol Process 12:1611-1625

Hickler T, Smith B, Sykes MT, Davis MB, Sugita S, Walkers K (2004) Using a generalized vegetation model to simulate vegetation dynamics in north-eastern USA. Ecology 85:519-530

Houghton JT, Ding Y, Griggs DJ, Nouger M, van der Linden PJ, Dai X, Maskell K, Johnson CA (2001) Climate Change 2001. The scientific basis, contribution of Working Group I to the Third Assessment Report of the Governmental Panel on Climate Change. Cambridge University Press, Cambridge

Hurrel JW, Kushnir Y, Visbeck M, Ottersen G (2003) An overview of the north atlantic oscillation. In: Hurrel JW, Kushnir Y, Ottersen G, Visbeck M (eds) The North Atlantic Oscillation: climate significance and environmental impact. Monograph, vol 134. American Geophysical Union, Washington, DC, pp 1-35

Jacob D (2001) A note to the simulation of annual and inter-annual variability of water budget over the Baltic Sea drainage basin. Meteorol Atmos Phys 77:61-73

Jacob D, Podzun R (1997) Sensitivity studies with the regional climate model REMO. Meteorol Atmos Phys 63:119-129

Jacob D, Goettel H, Jungclaus J, Muskulus M, Podzun R, Marotzke J (2005) Slowdown of the thermohaline circulation causes enhanced maritime climate influence and snow cover over Europe. Geophys Res Lett 32:L21711

Keup-Thiel E, Goettel H, Jacob D (2006) Regional climate simulations for the Barents Sea region. Boreal Environ Res 11:329-339

Kimball JS, Keyser AR, Running SW, Saatchi SS (2000) Regional assessment of boreal forest productivity using an ecological process model and remote sensing parameter maps. Tree Physiol 20:761-775

Koca D, Smith B, Sykes MT (2006) Modelling regional climate change effects on potential natural ecosystems in Sweden. Clim Change 78:381-406

Lehmann AP, Lorenz P, Jacob D (2004) Modelling the exceptional Baltic Sea inflow events in 2002-2003. Geophys Res Lett 31:L21308

Lynch AH, Chapman WL, Walsh JE, Weller G (1995) Development of a regional climate model of the western arctic. J Climate 8:1555-1570

Lynch AH, McGinnis DL, Bailey DA (1998) Snow-albedo feedback and the spring transition in a regional climate system model: Influence of land surface model. J Geophys Res 103:29037-39049

Lynch AH, Maslanik JA, Wu W (2001) Mechanisms in the development of anomalous sea ice extent in the western Arctic: A case study. J Geophys Res 106:28097-28105

Lynch AH, Curry JA, Brunner RD, Maslanik JA (2004) Toward an integrated assessment of the impacts of extreme wind events on Barrow. Bull Am Meteorol Soc 85:209-221

Majewski D (1991) The Europa-Modell of the Deutscher Wetterdienst. In: ECMWF Seminar on Numerical Methods in Atmospheric Models, vol 2, pp 147-191

Oberhuber JM (1993) The OPYC ocean general circulation model. Report no. 7. Deutsches Klimarechenzentrum $\mathrm{GmbH}$, Hamburg

Olson JS (1994) Global ecosystem framework - definitions. USGS EROS Data Center Internal Report, Sioux Falls, p 37

Pfeifer S, Jacob D (2005) Changes of the Arctic Climate under the SRES B2 Scenario Conditions simulated with the Regional Climate Model REMO. Meteorol Z 16:711-719 
Prentice I, Cramer W, Harrison S, Leemans R, Monserud R, Solomon A (1992) A global biome model based on plant physiology and dominance, soil properties and climate. J Biogeogr 19:117-134

Przybylak R (2002) Variability of air temperature and atmospheric precipitation in the arctic. Atmos Oceanogr Sci Libr 25:1-330

Raschke E, Meywerk J, Warrach K, Andrae U, Bergstroem S, Beyrich F, Bosveld F, Bumke K, Fortelius C, Graham LP, Gryning SE, Halldin S, Hasse L, Heikinheimo M, Isemer HJ, Jacob D, Jauja I, Karlsson KG, Keevallik S, Koistinen J, van Lammeren A, Lass U, Launiainen J, Lehmann A, Liljebladh B, Lobmeyr M, Matthäus W, Mengelkamp T, Michelson DB, Napiorkowski J, Omstedt A, Piechura J, Rockel B, Rubel F, Ruprecht E, Smedman AS, Stigebrandt A (2001) BALTEX (Baltic Sea Experiment): A European Contribution to Investigate the Energy and Water Cycle over a Large Drainage Basin. Bull Am Meteorol Soc 82:2389-2413

Raschke E, Karstens U, Nolte-Holube R, Brandt R, Isemer HJ, Hoffmann D, Lobmeyer M, Rockel B, Stuhlmann R (1998) The Baltic Sea Experiment BALTEX: a brief overview and some selected results of the authors. Surv Geophys 19:1-22

Rechid D, Jacob D (2006) Influence of seasonally varying vegetation on the simulated climate in Europe. Meteorol Z 15:99-116

Rinke A, Dethloff K, Cassano JJ, Christensen JH, Curry JA, Du P, Girard E, Haugen JE, Jacob D, Jones CG, Koltzow M, Laprise R, Lynch AH, Pfeifer S, Serreze MC, Shaw MJ, Tjernström M, Wyser K, Zagar M (2006) Evaluation of an ensemble of Arctic regional climate models: spatiotemporal fields during the SHEBA year. Clim Dyn 26:459-472

Robinson DA, Kukla G (1985) Maximum surface albedo of seasonally snow covered lands in the northern hemisphere. J Clim Appl Meterol 24:402-411

Roeckner E, Arpe K, Bengtsson L, Christoph M, Claussen M, Dümenil L, Esch M, Giorgetta M, Schlese U, Schulweida U (1996) The atmospheric general circulation model ECHAM4: model description and simulation of present-day climate. Report no. 218. Max-Planck Institute für Meteorologie, Hamburg

Roeckner E, Bengtsson L, Feichter J, Lelieveld J, Rohde H (1999) Transient climate change simulations with a coupled Atmosphere-Ocean GCM including the tropospheric sulfur cycle. J Climate 12:3004-3032

Rouse WR (1984) Microclimate at Arctic tree line, radiation balance of tundra and forest. Water Resour Res 20:57-66

Schurgers G, Mikolajewicz U, Gröger M, Maier-Reimer E, Vizcaíno M, Winguth A (2007) The effect of land surface changes on Eemian climate. Clim Dyn 20:357-373

Sitch S, Smith B, Prentice I, Arneth A, Bondeau A, Cramer W, Kaplan J, Levis S, Lucht W, Sykes M, Thonicke K, Venevsky S (2003) Evaluation of ecosystem dynamics, plant geography and terrestrial carbon cycling in the LPJ Dynamic Global Vegetation Model. Glob Chang Biol 9:161-185

Smith B, Prentice IC, Sykes MT (2001) Representation of vegetation dynamics in modelling of European ecosystems: comparison of two contrasting approaches. Glob Ecol Biogeogr 10:621-637

Strack JE, Liston GE, Pielke RA (2004) Modeling snow depth for improved simulation of snow-vegetationatmosphere interactions. J Hydrometeorol 5:723-734

Wagner F (1998) The influence of environment on the stomatal frequency in Betula, LPP Contributions Series No. 9, Laboratory of Paleobotany and Palynology, University of Utrecht. p 102

Wigmosta MS, Vail L, Lettenmaier DP (1994) A distributed hydrology-vegetation model for complex terrain. Wat Resour Res 30:1665-1679

Wolf A, Blyth E, Harding R, Jacob D, Keup-Thiel E, Goettel H, Callaghan T (2007) Sensitivity of an ecosystem model to hydrology and temperature. Clim Change (in this issue) 